\title{
ALAN MOZLEY: AN AMERICAN MALACOLOGIST IN SIBERIA (1932-1933)
}

\author{
MAXIM V. VINARSKI
}

Saint-Petersburg State University, 7/9 Universitetskaya Emb, 199034 Saint-Petersburg; St. Petersburg Branch of S. I. Vavilov Institute for the History of Science and Technology of Russian Academy of Sciences, 5/2 Universitetskaya Emb., 199034, Saint-Petersburg, Russian Federation (e-mail: radix.vinarski@gmail.com)

ABSTRACT: The history of malacological exploration of Siberia, made in 1932 and 1933 by the malacologist Alan Mozley, then affiliated with the Smithsonian Institution, USA, is given, with a discussion of his contribution to the knowledge of taxonomy, biogeography and ecology of freshwater and terrestrial molluscs of Northern Asia. The type specimens of the Siberian species and subspecies, described as new by Mozley, are illustrated, with remarks on the current taxonomic status of these taxa. A social-historical context of Mozley's trip to Stalin's Russia is also provided, including its connection to the prosecution of Nikolay Vavilov, a key opponent of "Lysenkoism".

KEY WORDS: Siberia; continental molluscs; history of malacology; biogeography; USSR

\section{INTRODUCTION}

The Soviet Union under Joseph Stalin's rule (around 1929-1953) is commonly portrayed as an isolationist and anti-Western state, strongly suspicious of people and ideas coming from the "bourgeois world'. Fundamentally, this picture is true, if simplistic. However, the scientific contacts between Soviet and Western researchers were never totally suppressed, and sometimes students from abroad were able to penetrate Stalin's Russia and conduct research in the midst of this huge country during a period of political and economic turmoil.
Alan Mozley's 1932-1933 zoological trip to Siberia is one of these rare cases which contradict the often-expressed view of the total cultural and scientific isolation of the Soviet Union from the West. Here I provide a brief account of Mozley and his Siberian travels, which may be interesting not only to malacologists but also to historians who are studying the Soviet-American scientific relations of the 1930s.

\section{ALAN MOZLEY (1904-1971): THE MALACOLOGIST'S BRIEF BIOGRAPHY}

The sources for reconstructing Alan Mozley's curriculum vitae and scientific career are a short biographical sketch authored by RAPPAPORT \& SOMERS (2003) as well as his own published works that often contain information on his travels, affiliations, awards, and research interests. The content of this section is derived from these sources, and from contemporaneous newspaper articles.
Born as a son of a clerk ("a company registrar") who lived in London, Walter Alan Mozley (Figs 1-2) later emigrated to Manitoba, Canada, with the rest of his family. At the age of eighteen, he was an amateur naturalist interested mostly in the life of temporary ponds in the environs of Winnipeg, with particular emphasis on snails. In 1928, he obtained his BSc degree from Wesley College (predecessor to 

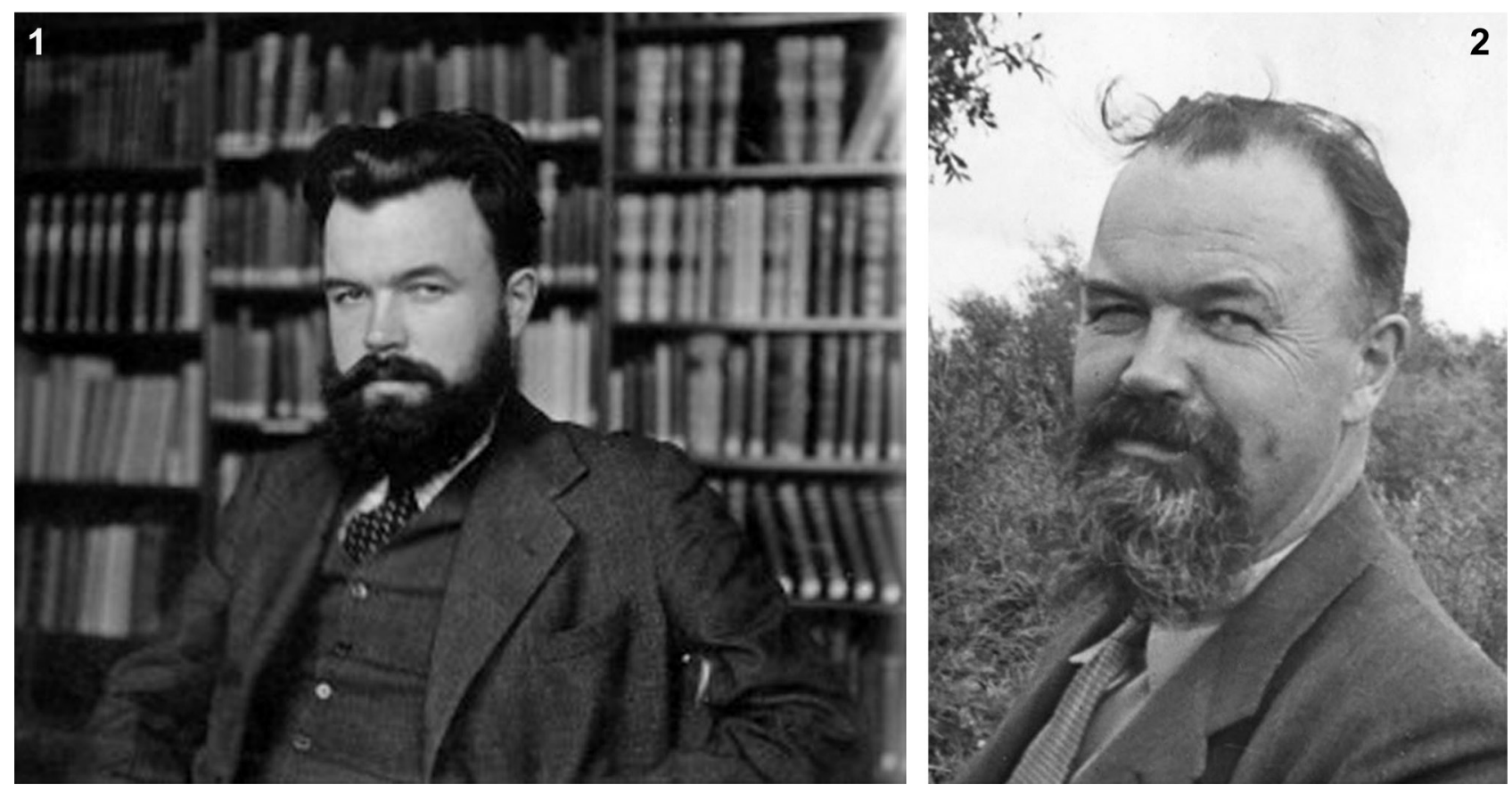

Figs 1-2. Two portraits of Walter Alan Mozley at different age: 1 - in the 1940s. The image taken and modified from the David Adams (a ballet dancer, and distant relative of Mozley) memorial site (URL: http://davidadams.org/david-adams-family-1940s/; accessed 11 January 2020); 2 - Mozley as an old man. Taken and slightly modified from the Manitoba Historical Society site (URL: http://www.mhs.mb.ca/docs/people/mozley_wa.shtml; accessed 19 August 2020)

the University of Winnipeg, Manitoba). After teaching for several years at prestigious US universities (Johns Hopkins University and University of North Carolina), he moved to Great Britain where, in 1932, he entered the PhD programme at Edinburgh University. In 1932 and 1933, Mozley spent two field seasons in Siberia and Kazakhstan, which became the first extended expedition in his professional career. The scientific results of this expedition earned him his $\mathrm{PhD}$, based on the thesis "The freshwater and terrestrial Mollusca of Northern Asia, with notes on the Mollusca of Fennoscandia" (MOZLEY 1934a). This thesis was later published in the Transactions of the Royal Society of Edinburgh (MOZLEY 1935).

Subsequently, he travelled extensively throughout the world, studying taxonomy, ecology and distribution of snails as well as their significance for public health, i.e., applied malacology, specifically parasitology. In 1940, Mozley was awarded the DSc degree from the University of Edinburgh; his thesis' title was "The fresh-water Mollusca of the Tanganyika territory and Zanzibar Protectorate, and other contributions to the systematics, bionomics, and distribution of fresh-water and terrestrial Mollusca" (this thesis was actually a compilation of reprints of three previously published research articles).

He was a keen traveller and preferred the outdoor life of a lonely wanderer, which had long restrained him from getting a regular tenured position at a university. Mozley spent many years working in the British colonies in Africa, as well as in Iraq, Egypt, Australia, and other countries. After World War II his scientific interests shifted towards studies of trematodiases (diseases spread by trematode flukes) and molluscs as fluke vectors; in the 1940s-1960s, he alternated between temporary appointments in various universities in the USA, Great Britain and Canada and activity as an expert in public health and snail control research. His longest academic appointment was at Union College (Schenectady, New York), where he was quite popular with the students (RAPPAPORT \& SOMERS 2003).

His first large monograph in malacology (MOZLEY 1935) was followed by a series of books devoted to varied aspects of ecology of freshwater snails (MOZLEY 1954), including their relationships with trematodes (MOZLEY 1944, 1951, 1957). He also authored about forty articles in the fields of descriptive and applied malacology as well as in physical geography (e.g., MOZLEY 1937a, b) and some other disciplines. His last books dealt chiefly with general problems of ecology.

Alan Mozley retired early from Union College, initially moving to western Canada where he lived with his sister's family (RAPPAPORT \& SOMERS 2003). He died in August 1971, aged 66, in Washington state, apparently of side effects of a tropical disease. 


\section{MOZLEY' JOURNEY IN SIBERIA AND ITS SCIENTIFIC RESULTS}

What was the main stimulus for Mozley to undertake a long and by no means safe travel across Siberia, which was then little explored by non-Russian naturalists?

In 1932, when Mozley first entered Asiatic Russia, the freshwater and terrestrial malacofauna of this country remained relatively poorly studied. Despite the efforts of some prominent zoologists such as Alexander von Middendorff, Leopold von Schrenck, Carl Ågardh Westerlund, Vassily Lindholm, Dybowski brothers (Władysław and Benedykt), whose studies of Siberian molluscs are discussed in my earlier publications (VINARSKI 2010, 2019), many parts of Siberia had never been visited by a malacologist, and even species lists, let alone detailed data on the ecology and distribution of continental Mollusca of Northern Asia, were not available. Though at least six large monographic works on this topic appeared before 1932 (VON MIDDENDORFF 1851, VON SCHRENCK 1867, WESTERLUND 1877, LINDHOLM 1909, W. DyвowsKi 1912, B. DybowsKi 1912), the geographical scope of each of these publications was rather restricted (except Westerlund's; this Swedish author attempted to overview the malacofauna of entire Siberia). Before Mozley, efforts were focused mainly on the systematic description of the fauna though some authors (e.g., Lindholm; see VINARSKI 2019) tried to discuss biogeographical and ecological questions as well.

Though Mozley contributed to molluscan taxonomy and faunal inventory, it seems that his major interest was in ecology and distribution of continental gastropods and bivalves. The relationships between molluscs and their habitats were the chief focus of his research in Northern Asia, which distinguished his approach from that of his prominent predecessors.

The Siberian trip was a part of a much broader research project, which was called by Mozley himself a "biological study of the Sub-Arctic Mollusca" (MOZLEY 1937b). He defined the Sub-Arctic region as the territory lying between the fiftieth parallel of northern latitude and the Arctic Circle. In Mozley's own words (cited by АвBOTT 1935a: 8), "the study of this problem is especially important, since in the Sub-Arctic we have the unique opportunity of investigating a fauna in the making. The whole of this region has only recently become habitable for mollusks, so that we are dealing, as it were, with an experiment in zoogeography, and there is an absolutely unparalleled opportunity for studying geographic distribution without the host of unknown geologic and geographic factors which often result in speculations which belong more in the realm of nature study or natural mythology than in science".

During this extensive study, Mozley attempted to address four general problems: " 1 . What is the constitution of the Sub-Arctic mollusc fauna? 2. From what geographical and phylogenetic sources has it been derived? 3. What environmental factors govern the distribution of species within the region? 4 . To what extent has the original immigrant stock been modified since its migration into the Sub-Arctic Region?" (MOZLEY 1937c: 149).

To accomplish this task, Mozley planned to analyse and compare the data on molluscan ecology and distribution collected from three large Sub-Artic regions: Canada, Scandinavia, and Siberia. By 1932, Mozley had an extensive body of original observations in Canada, accumulated during 1924-1931. The next two field seasons would be devoted to the exploration of northern Asia, and he would collect the data on Fennoscandian molluscs in 1934.

The funds for the Siberian expedition were provided by the Smithsonian Institution (Washington, USA) under a grant from the Walter Rathbone Bacon travelling scholarship (АввOTT 1933). This scholarship aimed to support studies "of the fauna of countries other than the United States of America" (MOZLEY 1934b: 1). According to the scholarship rules, all "collections, photographs, records, and equipment" obtained with its support, should become the property of the Institution (ANONYMOUS 1927). As a result, the malacological samples collected by Mozley in Siberia were deposited in the National Museum of Natural History (NMNH) (see below).

Most probably, Mozley was chosen by the Smithsonian for that expedition because he was not an American citizen; the US refused to recognise the Soviet Union until 1933. Despite the many years spent in the USA, Mozley for a long time retained his dual British/Canadian citizenship (A. KABAT, pers. comm.).

Unfortunately, his monograph (MOZLEY 1935) contained neither a map nor a detailed itinerary of the author's route. It is possible to provide here only a very general outline of his travel, based on the brief information published in the annual reports of the Smithsonian Institution (АввотT 1933, 1935a, b, 1937).

Mozley started his 1932 field season with a visit in Tomsk, a large city lying in the southern part of western Siberia. He was able to make an excursion to the mouth of the Ket' River (north of Tomsk) and another one south, into the Akmolinsk Steppe (nowadays the territory belongs to nothern and central Kazakhstan; Akmolinsk is now the capital of 


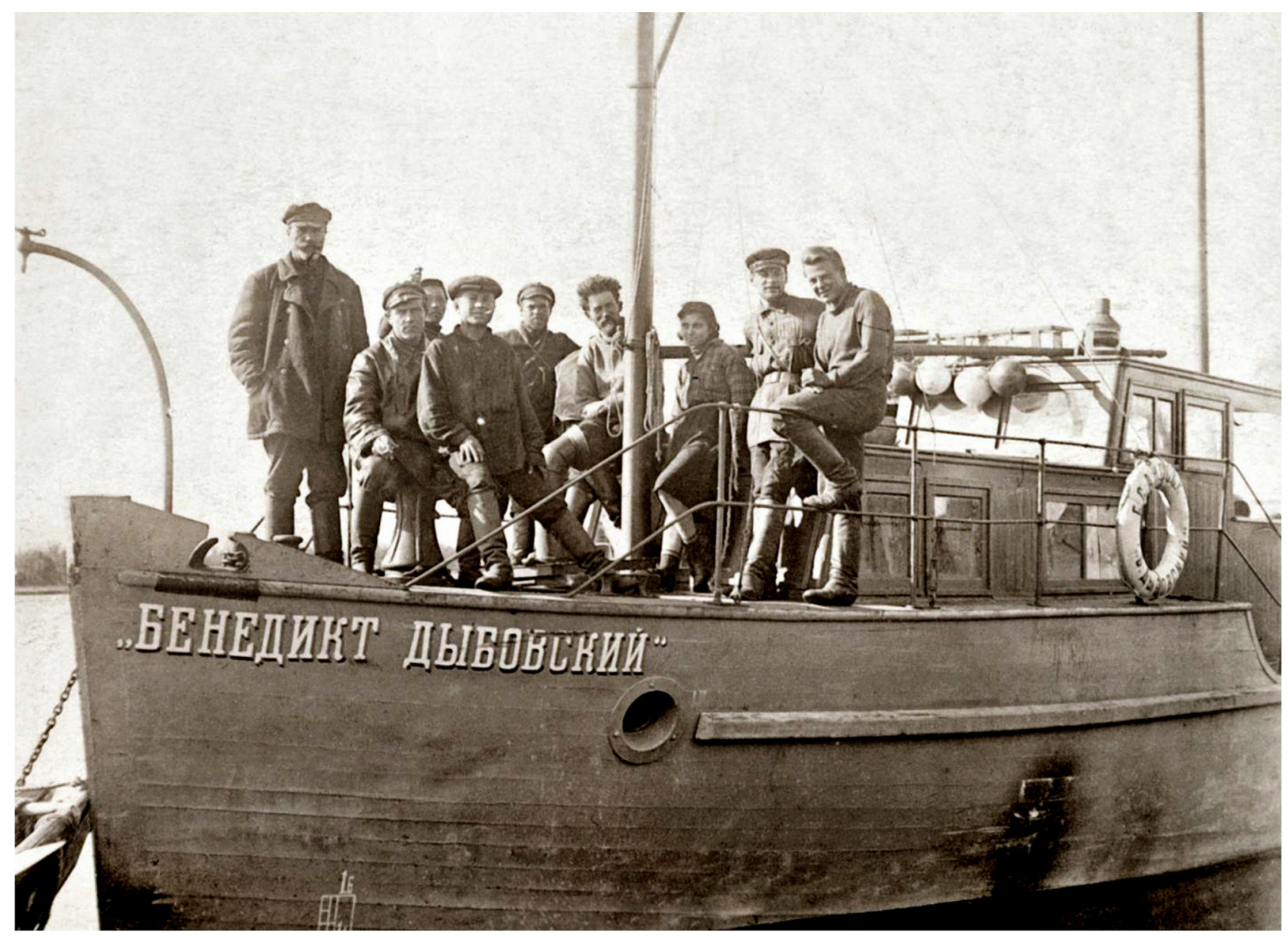

Fig. 3. R/V Benedykt Dybowski owned by the Baikal limnological station. Photo taken in 1931. After TAKHTEEV \& RUSINEK (2019). Most probably, next year Mozley worked on board of this vessel

Kazakhstan named Nur-Sultan). In the same year he managed to visit Lake Baikal, where "thanks to the generous assistance of the director of the limnological station at Lake Baikal, he was able to spend nearly 2 months in the Baikal region, where he circumnavigated the lake in the motor yacht of the station and made various land excursions" (АВвотT 1935a: 75). In these years, the Baikal limnological station (now Limnological Institute of the Siberian Branch of the Russian Academy of Sciences) was situated in Listvyanka settlement, approximately $50 \mathrm{~km}$ SE of Irkutsk. Its director, Prof. Gleb Vereshchagin (1889-1944), was a prominent Russian geographer and limnologist, one of the first explorers of Lake Baikal (TAKHTEEV \& RUSINEK 2019). The station owned a small research vessel named after Benedykt Dybowski (Fig. 3). Most probably, it was that "motor yacht" mentioned in the Smithsonian annual report.

In 1933, Mozley made a three-month journey through the forest-steppe to the south of Omsk (nowadays within Kazakhstan boundaries). That year the scholarship was extended to cover 1934, during which year Mozley planned to continue his research in Siberia. He intended to make a trip down the Lena
River and to explore the river and adjacent territory, "but for certain reasons it was not practicable for him to obtain the necessary permission for work in this territory" (ABBOTT 1937: 9). Having no possibility to reach the Lena River, Mozley spent the field season of 1934 in Scandinavia, where he studied continental molluscs of Finland and northern Sweden.

$\mathrm{He}$ spent the winters of 1932/1933 and 1933/1934 in Edinburgh working on his collections in Edinburgh University.

The primary results of the Siberian travel were published in two main publications, the first of which was a taxonomic paper with the description of new species and subspecies of aquatic molluscs (MOZLEY 1934b). The second one (MOZLEY 1935) was a lengthy publication (actually a monograph), with an annotated check-list of Siberian freshwater and terrestrial Mollusca and a detailed discussion of their ecology and biogeography. A short faunal note devoted to the discovery of a land snail Zoogenetes harpa (Say, 1824) in Siberia (MOZLEY 1934c) became the third published outcome of the expedition.

Later, Mozley used his observations from northern Asia for comparative ecological analyses (MOZLEY 
1937c, 1938) as well as in his book on the general ecology of freshwater Mollusca (MOZLEY 1954).

I have tried to reconstruct his routes based on the lists of species' occurrences given in his articles (Fig. 4). Despite this effort, some of the localities remain unknown or uncertain due to either mistakes in transliterations of Russian and Kazakh geographic names made by Mozley himself (for example, "Chernoredsky" on the Irtysh River; possibly it is Chernoluchye, a settlement near Omsk) or the subsequent renaming or even complete disappearance of settlements and locations visited by him almost a century ago.

Possibly, not all the mollusc localities mentioned in the 1935 paper were actually visited by the author himself. It is known that during his journey Mozley visited the largest university centres of Siberia, including Irkutsk, Omsk and Tomsk, and contacted local experts on the freshwater fauna. Thus, in Tomsk, he met a young ichthyologist Bodo Johansen (Ioganzen) (1911-1996), who would later become the leading malacologist of Siberia. In Omsk, he communicated with Prof. Pyotr Dravert (1879-1945), a naturalist and poet, who was interested in many disciplines, from mineralogy and zoology to the study of meteorites and ethnology. In the 1930s, both Johansen and Dravert published articles on freshwater molluscs of Siberia (JOHANSEN 1934, DRAVERT 1935). MOZLEY (1935: 607) mentioned that he investigated the "useful collection" of Johansen during his stay in Tomsk.
Nevertheless, the area covered by Mozley himself was enormous. He made "extensive travels about the lake" Baikal (MOZLEY 1954: 31), visited the southern parts of western Siberia and the dry steppes of northern Kazakhstan. In the course of two seasons, Mozley explored some parts of what are now the Altay, Omsk, Novosibirsk, Tomsk and Irkutsk oblasts [regions] of Russia as well as the Akmola and Pavlodar oblasts of modern Kazakhstan (Fig. 4). The southernmost point of Siberia he reached was Ulala Town, today Gorno-Altaysk, the capital of the Altay Republic. From his memoirs, we know that Mozley travelled alone, "except for a Russian boy to tend the horses" (RAPPAPORT \& SOMERS 2003). He made use of the Trans-Siberian railway, but most of his way through the Siberian wilderness was made by horse-and-cart. The list of continental Mollusca taxa of Northern Asia, published by MOZLEY (1935), contained 37 species and subspecies of aquatic gastropods, 17 species and subspecies of terrestrial snails, and 14 species of mussels and pea-clams. Not all of them were actually present in the author's collection; some taxa were included in the list based on data in the prior literature. Mozley also had an opportunity to examine several available private and museum collections of Sub-Arctic molluscs, including those of the Tomsk State University (Siberia's first university).

Among the taxa he found, eight were described by MOZLEY (1934b) as new. The type series of these

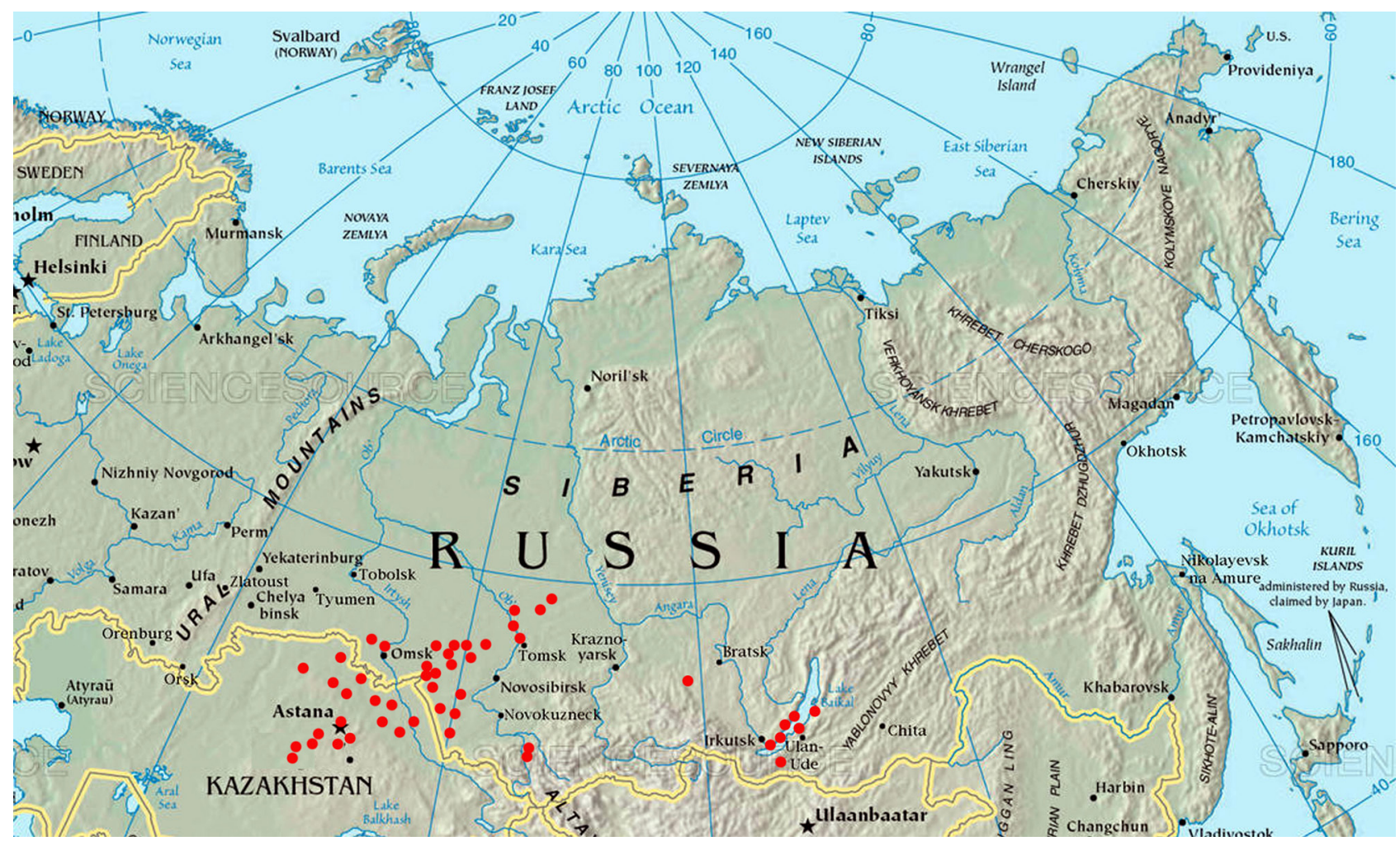

Fig. 4. Map of Mozley's fieldwork in Siberia, 1932 and 1933, based on species occurrences mentioned in MOZLEY (1934a, b, c, 1935) 
taxa are now in the Smithsonian's NMNH and photos of syntypes of all these species and subspecies save Physa sartlandinensis Mozley, 1934 (type no longer extant) are published herein (Figs 5-12). These are:

1. Valvata antiquilina Mozley, 1934 (MOZLEY 1934b: 1, pl. I, fig. 4; 1935: 612). Type locality - "Lake Khomotenoye, Aj-Bulat drainage basin, Siberia", which corresponds to Lake Khomutinoye, situated in the Altay Krai of Russia, near Burla settlement, approximately $53^{\circ} 26.6^{\prime} \mathrm{N}, 78^{\circ} 41.6^{\prime} \mathrm{E}$ (see VINARSKI \& KANTOR 2016). The true identity of the species is uncertain; it is possibly a junior synonym of the Euro-Siberian Valvata antiqua Morris, 1838 (VINARSKI \& KANTOR 2016). USNM 469212, 1 syntype (Fig. 5).

2. Lymnaea (Galba) palustris saridalensis Mozley, 1934 (Mozley 1934a: 2, pl. I, fig. 1; 1935: 626). Type locality - Northern Kazakhstan, small, brackish lake in the Steppe Sari Dala, $15 \mathrm{~km}$ southwest of Pavlodar. The syntypes and their taxonomic identity were discussed in my earlier paper (VINARSKI 2014). The current systematic position of this taxon is: Stagnicola saridalensis (Mozley, 1934), a valid species. USNM 469734, 10 syntypes (Fig. 6).

3. Lymnaea (Galba) palustris kazakensis Mozley, 1924 (MoZley 1934b: 3, pl. I, fig. 7; 1935: 628). Type locality - Northern Kazakhstan, small dry lake bottom near the village of Novo Troetskaya (it proved to be impossible to locate the locus typicus exactly). In current taxonomy this subspecies is accepted as valid; its proper name is Lymnaea (Kazakhlymnaea) taurica kazakensis Mozley, 1934 (VINARSKI et al. 2012, VINARSKI \& KANTOR 2016). USNM 470457 (Fig. 7).

4. Lymnaea (Galba) palustris draverti Mozley, 1934 (MoZley 1934b: 4, pl. I, fig. 9; 1935: 629). Type locality - Siberia, from the River Om near Omsk. It is a junior synonym of Stagnicola saridalensis (VINARSKI 2014, VINARSKI \& KANTOR 2016). USNM 469681, 12 syntypes (Fig. 8).

5. Lymnaea (Galba) palustris bolotensis Mozley, 1934 (Mozley 1934b: 5, pl. I, fig. 3; 1935: 630). Type locality - Northern Kazakhstan, "from flooded area between the Rivers Chaganak and Chederti, Djarla-Uli drainage basin". This area belongs now to either Akmola oblast or Pavlodar oblast of Kazakhstan. The subspecies epithet is derived from Russian "boloto", a swamp, and apparently does not indicate any particular location. The subspecies is currently regarded as a synonym of Ladislavella terebra (Westerlund, 1885) (VINARSKI 2012, VINARSKI \& KANTOR 2016). USNM 469821, holotype (Fig. 9).

6. Lymnaea (Radix) zazurnensis Mozley, 1934 (MOZLEY 1934b: 6, pl. I, fig. 2; 1935: 623). Type locality is given as "Lake Zazurnia, in the mountain range known as Khamar Daban, eastern shore of the
Lake Baikal". There is no lake bearing such a name in Eastern Siberia. According to a reasonable hypothesis, the type series was collected from Lake Sobolinoye situated south of Vydrino station $\left(51^{\circ} 17.8^{\prime} \mathrm{N}, 104^{\circ} 41.25^{\prime} \mathrm{E}\right)$ (see VINARSKI \& KANTOR 2016). USNM470709, 1 syntype (Fig. 10). The current taxonomic allocation of this snail is as a synonym of Kamtschaticana kamtschatica (Middendorff, 1851) (VINARSKI, unpublished).

7. Planorbis (Spiralina) johanseni Mozley, 1934 (MOZLEY 1934b: 6, pl. I, fig. 8; 1935: 637). Type locality - Kazakhstan, "Kotur Kulb near Borovoye" (an unidentifiable locality). It is a junior synonym of Anisus vortex (Linnaeus, 1758) (VINARSKI \& KANTOR 2016). USNM470515, 14 syntypes (Fig. 11).

8. Physa sartlandinensis Mozley, 1934 (MOZLEY 1934b: 7, pl. I, fig. 6; 1935: 641). Type locality: Russia, Novosibirsk Region, Barabinsk Steppe, Sartlan Lake. The type specimens of this species were not found in the USNM collection (YURY KANTOR, pers. comm.). TAYLOR (2003) mentioned that the holotype of $P h$. sartlandinensis was kept in the USNM, but it is unclear from his text if Taylor himself had seen the holotype. There are two other lots of this species in the USNM, both collected by Mozley but neither from the type locality (NMNH 469614 \& 469617). The taxonomic position of this species remains unclear. While TAYLOR (2003) placed it in the synonymy of Physa dalmatina Küster, 1844, whose type locality is situated in the Balkan Peninsula, Russian authors regard it as taxon inquirendum (VINARSKI \& KANTOR 2016). In August of 2005, I visited Lake Sartlan and tried to collect topotypes of $\mathrm{Ph}$. sartlandinensis but was unsuccessful.

Importantly, the description of these new taxa was not the main focus for Mozley, whose research project was centred around ecology and biogeography. In his 1935 paper, he described in detail the habitat distribution of aquatic molluscs (including those living in salt lakes of the Altay and Kazakh steppe). He gave a hydrological characteristic of the main types of aquatic habitats in southern Siberia in relation to the fauna of molluscs inhabiting them. Mozley developed a zoogeographic regionalisation of Northern Asia and divided this subcontinent into four faunal regions: the Great Siberian Region, the Baikal Region, the Far Eastern Region, and the Chukchee-Kamchatka Region. He did not visit the last two regions personally, and he based their delineation on the results of an extensive study of literature sources and museum collections.

To sum up, Mozley's opus magnum (MOZLEY 1935) was the first ecological-geographical monograph on the continental Mollusca of Northern Asia. Albeit based on what is now an outdated taxonomy, in some respects this work has remained unmatched till the 


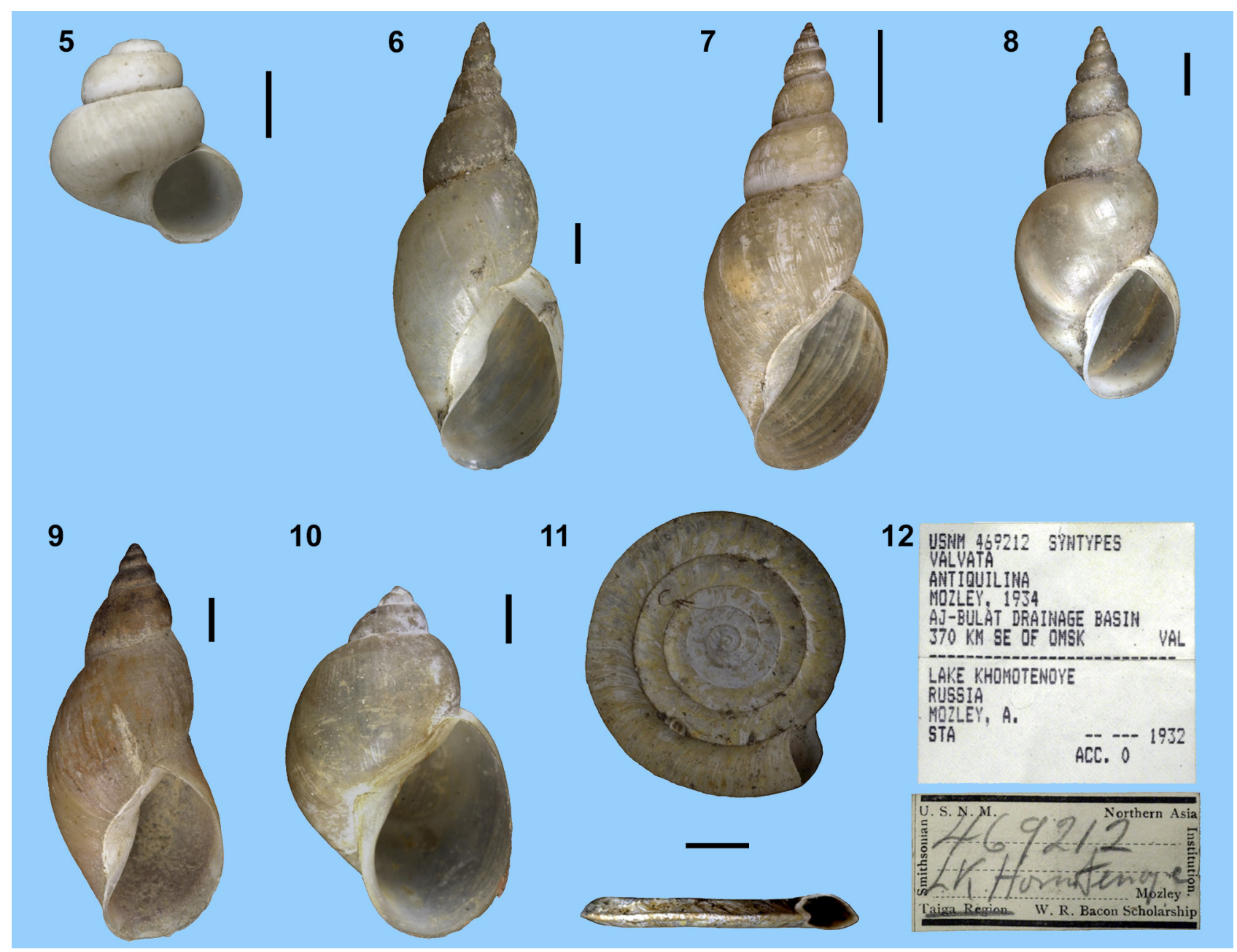

Figs 5-12. Type specimens (5-11) and an example of a museum label (12) of species of Siberian snails described by MOZLEY (1934) as new to science: 5 - Valvata antiquilina, 6 - Lymnaea palustris saridalensis, 7 - L. palustris kazakensis, 8 - L. p. draverti, 9 - L. p. bolotensis, 10 - L. zazurnensis, 11 - Planorbis johanseni (two views). Scale bars $2 \mathrm{~mm}$ (except 6 - $5 \mathrm{~mm}$ )

present day. Only one substantial component of the Siberian malacofauna - the highly endemic malacofauna of Lake Baikal - was almost completely ignored by Mozley, even though he spent significant time at the limnological station on Lake Baikal and was able to use the station's yacht for extended cruises along the shoreline (Аввотт 1933). This gap was already addressed in 1936 when Mikhail Kozhov published his taxonomic monograph on the molluscs of Baikal (KozHOV 1936).

The general reader of the 1930s could obtain information about Mozley and his Siberian trip mainly from newspaper articles and interviews. The most unusual outcome of this, apparently unexpected by Mozley himself, became a story of "Siberian Snails and Life on Mars" which is briefly presented below (based mostly on personal communication of ALAN KABAT).

MOZLEY (1935: 670-671, 686) explained that the Siberian snails had to be able to survive winter temperatures as cold as 40 degrees below zero or even colder. Somehow, the science reporter for the New York Times picked up on this, and either Mozley him- self, or the reporter, jumped to the conclusion that snails would be able to survive the temperatures on the planet Mars, which was then known to have extremely cold temperatures. This conclusion, which Mozley may have made as a joke, was picked up by the national press in the USA, starting with the New York Times in the Sunday paper on 12 January 1936. This article presented a sober discussion of Mozley's conclusions about snails surviving the cold Siberian winter, which the reporter likened to "quasi-Martian conditions" and the reporter concluded that "all this makes one speculate the more about the possibilities of life on Mars" (KAEMPFFERT 1936). This speculation by Mozley and/or the science reporter was then circulated by the Associated Press (a national newswire service) and republished on the very next day by several other major newspapers, this time attributed directly - and incorrectly! - to Mozley.

It is enough to cite here only one example of a newspaper speculation on the topic. An anonymous commentary went on to present Mozley's "conclusions" about Martian geography: "The changes on 
Mars' surface that have so puzzled [others] are now generally believed to be caused by annual meltings of ice and snow at its poles. The water runs into shallow depressions, Dr. Mozley believes, and there remains for a month or so, long enough to bring forth the vegetation that shows in dark areas through the telescopes and to afford opportunity for the breeding and feeding of a cycle of molluscs. The ponds run dry; the vegetation survives in seeds, the snails as adults in winter dormancy, awaiting the life-giving moisture of a new spring. It is a theory to arouse speculation. Are these snails, if they are such, the surviving life of an evolution starting hundreds of millions of years ago, reaching a zenith of perhaps a high order of plant and animal being and then literally running out for lack of the means of subsistence? Or are they the height of evolution's processes on Mars? If the latter guess is correct, it becomes obvious that a race proverbially slow can never rise to a station of physical or mental attainment comparable to man's on earth, can never be capable of thinking out and setting up equipment to send or receive messages from any other planet in this or other universes. Mars will die and the snail will still be a snail" (ANONYMOUS 1936a).

Remarkably, at approximately the same time, i.e. in the mid-thirties, Gavriil Tikhov, a Russian astronomer, developed a new branch of science and called it "astrobotany". TIKHOV (1949) tried to explain the observed changes in Mars surface coloration by vegetation cycles. As far as I know, he did not mention either snails or any other animals in his publications on astrobotany.

Needless to say that Mozley himself did discuss the Siberian molluscs in the "astrobiological" context neither in his Siberian monograph (MOZLEY 1935) nor in his other publications on the Siberian malacofauna. As far as is known, Mozley is the only malacologist whose research was discussed, however erroneously, in connection with the likelihood of extraterrestrial life.

\section{HUNGER AND TERROR: THE POLITICAL BACKGROUND OF MOZLEY'S TRAVEL}

The years 1932 and 1933 were especially hard for the people of the USSR. Due to the collectivisation and the cessation of the "new economic policy" (known as NEP), a serious economic crisis had taken over the country (OsOKINA 2008). City dwellers suffered from a sharp deficiency of food and many consumer goods, whereas in the rural regions of Ukraine, South Siberia, and North Kazakhstan, people were actually starving to death. Mozley discussed this in his memoirs and even remarked on it in his scientific publications. For example, in his 1935 article, he discussed finding large freshwater mussels of the genus Unio in the River Tom'. It would be a significant discovery from both taxonomic and biogeographical point of view since it was thought that the Unio mussels did not live in Siberia (ZHADIN 1933). However, Mozley was unable to add it to his collection because "the specimens were stolen by some hungry natives while they were being brought out of Tomsk" (MOZLEY 1935: 651).

Some strange and inexplicable things happened during his travel along the Trans-Siberian Railway. As Mozley himself recalled it, during his journey on the Trans-Siberian Railway his "fellow passengers mysteriously disappeared one by one"; in the Kazakh steppe, he met hungry men who "would kill for food. The usual method was to cut the throat" (RAPPAPORT \& SOMERS 2003: 499-500). Travelling in a rather dangerous country, Mozley took some precautions. As one Australian newspaper informed their readers, he "grew a flowing coal-black beard when in Siberia in order to look more Russian, and thus avoid awkward questions about his nationality" (ANONYMOUS 1936b).
However, it seems that Mozley had no serious problems with Soviet officials and policemen during his two-year trip. At all accounts, he could work safely even in the wildest places of Siberia. In a publication, he expressed his thanks to many unnamed Soviet "scientific men and officials" for their cordial assistance, and "it was through their aid that I was able to travel so extensively in the more remote and less populated parts of the country" (MOZLEY 1935: 606; see also ABBOTT 1933: 25). Troubles arose some years after Mozley left the USSR. These troubles did not touch him personally but some of these "scientific men", who helped the American to "travel so extensively".

The Academician Nikolay Vavilov (1887-1943), the leading Soviet geneticist of that epoch, was in the late 1930s one of the strongest and most prominent opponents of Lysenko and his so-called "Michurinist biology" which stemmed from a bitter hostility towards the Mendelian genetics, rejected as a "bourgeois science" in favour of Lysenko's own theory that the environment alone induced heritable changes in plants and animals. This infamous theory became known as "Lysenkoism" (see KREMENTSOV 1997, POLLOCK 2009 and references therein). Although Lysenko's research is now known to be irreproducible "junk science," at the time his views were highly influential, being approved by Stalin and continuing through the Khrushchev years (MEDVEDEV 1969, DOBZHANSKY 1980).

Vavilov was arrested in 1940 and, only three years later, starved to death in the Saratov prison. The sledstvennoe delo [investigation material] of his case was 
published only twenty years ago (ROKITYANSKY et al. 1999). As it turns out, Stalin's investigators used Mozley's visit to the USSR in 1932-1933, which was organised with the Academician's support, as a corpus delicti against Vavilov, who was accused of espionage. Mozley himself, seven years after he left Russia, was also suspected of being a spy. According to Vavilov's sledstvennoe delo, during his stay in Omsk "in conversation with the administration of the Grain Crops Institute, Mozley aroused suspicion about the validity of his scientific qualifications and the serious scientific goals of his trip to Siberia. While in Omsk, Mozley seemed interested in information on the number of guns and local factories that carried out orders of the military department" (ROKITYANSKY et al. 1999: 459-460).

The absurdity of this accusation may be compared only to the absurdity of accusations against Vavilov himself. In particular, Vavilov was suspected, since 1925, as the leader of the so-called "Labour Party of the Peasantry" who allegedly was actively planning a plot against the Soviet regime. In August of 1955, soon after Stalin's death, the Supreme Court of the USSR dropped all charges from Vavilov's record; he was found not guilty of espionage and other crimes ascribed to him in 1940-1941. Unfortunately, Vavilov had died in 1943, over a decade prior to his posthumous exoneration.

The published text of Vavilov's interrogation contains some hitherto unpublished details about Mozley's research trip to the USSR. I provide a translation of some excerpts from Vavilov's sledstvennoe delo (ROKITYANSKY et al. 1999: 235).

- "Question: Did you invite Mozley, the American zoologist, to visit the USSR?

- Answer: No. I did not invite him.

- Q: Are you the person who applied to Narkomindel to approve the Soviet visa for Mozley? [Narkomindel (Narodnyi Komissariat Inostrannykh Del) - at that time the name of the Soviet Ministry of Foreign Affairs]

- A: I do not remember. Perhaps I did it.

- Q: Were you well familiar with Mozley?

- A: No, I saw him only once, for 15 minutes.

- Q: Did you give him a recommendation letter addressed to land departments and agricultural institutions of the USSR?

- A: Yes, I did.

- Q: Why did you, not knowing this man, write the petition to grant him the Soviet visa, and give him the recommendation letter addressed to the Soviet institutions that were asked to support him during his travel through the USSR?

- A: I behaved in such a manner because [Mozley] had a recommendation letter from an American university's President, who asked to help Mozley in his research trip to the USSR.
- Q: Which topics were studied by Mozley and which regions of the Union he visited?

- A: Mozley's speciality is zoology, and he went [to the USSR] to study molluscs and explore Siberian lakes and swamps.

- Q: Did Mozley travel alone in Siberia or was he a member of some expedition?

- A: I cannot recall it but it seems that I did write a petition to the Academy of Sciences in order to let Mozley be included in one of the expeditions sent to Siberia.

- Q: But how to explain that you were especially caring to this man, whom you did not know personally and whose scientific work has nothing to do with your field of research?

- A: I did it following the common custom [to help] someone who has arrived with recommendation letters from prominent scientists or scientific institutions of foreign countries.

- Q: You are concealing the true motives of your assistance to foreigners during their stay in the USSR and your criminal relations with some of them! We demand honest testimonies!

- A: My testimony is honest, I'm telling you all as it was in reality. I have never had illegal relations with the foreigners".

This interrogation illustrates the mechanism of academic exchange between the USSR and the USA in those years and explains some circumstances that allowed Mozley to undertake his trip. It is obvious that Vavilov never had close relations with Mozley, and the support he provided the American was because of the scientific ethic and the spirit of collegiality between researchers of different countries. However, from the investigator's point of view, Vavilov's conduct was a deceptive camouflage, which hid the allegedly "true" motivation - espionage.

However unusual Mozley's lonely travel through Siberia may seem, the very fact of his two-year stay in the Soviet Union is not all that surprising. In the early 1930s, the scientific exchange between the USA and the USSR was relatively active. With financial support from the Rockefeller Foundation, several leading Russian biologists (Vladimir Alpatov, Dmitry Kashkarov, and Anton Zhebrak) were doing their research in the USA (KREMENTSOV 1997). Another biologist, who decided not to return home, became one of the founders of the Modern Synthesis in evolutionary biology (Theodosius Dobzhansky). Yet another genius lost to Russia was George Gamow [Georgiy Gamov], the physicist, who went on to formulate the Big Bang theory. There was also some movement in the opposite direction. One of the most eminent American biologists who went to the USSR to do scientific research from 1934 to 1937, was the geneticist Herman Muller, who returned to the USA and later won the Nobel prize in 1946. 
After the December 1934 murder of Sergei Kirov, a popular politician, whom Stalin thought to be his main rival, scientific and other contacts with the West dwindled and eventually almost entirely ceased. Soviet science eventually turned into "a huge, hierarchical, centralized, politicized, isolated, and strictly controlled system" (KREMENTSOV 1997: 13). I am unaware of any foreign malacologist who conducted fieldwork in the USSR between 1935 and the mid-1960s (although in some German zoological museums one can find freshwater molluscs collected during World War II from the territory of the USSR occupied by the Nazi troops; presumably these collections were made by soldiers with scientific background or interested in natural history). Thus, Mozley's malacological trip through Siberia can be considered as a unique event in the history of Stalinist science, and one that, evidently unknown to Mozley, resulted in harsh consequences for Nikolai Vavilov.

\section{REFERENCES}

Аввотт C. G. 1933. Report of the Secretary of the Smithsonian Institution for the year ending June 30, 1932. Annual Report of the Board of Regents of the Smithsonian Institution, showing the operations, expenditures, and condition of the Institution for the year ending June 30, 1932. United States Government printing office, Washington: 1-89.

Аввотт C. G. 1935a. Report of the Secretary of the Smithsonian Institution for the year ending June 30 1933. Annual Report of the Board of Regents of the Smithsonian Institution, showing the operations, expenditures, and condition of the Institution for the year ending June 30, 1933. United States Government printing office, Washington: 1-68.

Аввотт C. G. 1935b. Report of the Secretary of the Smithsonian Institution for the year ending June 30, 1934. Annual Report of the Board of Regents of the Smithsonian Institution, showing the operations, expenditures, and condition of the Institution for the year ending June 30, 1934. United States Government printing office, Washington: 1-69.

Аввотт C. G. 1937. Report of the Secretary of the Smithsonian Institution for the year ending June 30, 1936. Annual Report of the Board of Regents of the Smithsonian Institution, showing the operations, expenditures, and condition of the Institution for the year ending June 30, 1936. United States Government printing office, Washington: 1-96.

ANONYMOUS 1927. The Walter Rathbone Bacon scholarship. Science 66: 445. https://doi.org/10.1126/science.66.1715.445

ANONYMOUS 1936a. Those "men" of Mars. Los Angeles Times, 16 January 1936, page A-4. (not seen; communicated by ALAN KABAT)

\section{ACKNOWLEDGEMENT}

I express my gratitude to YURI KANTOR (Moscow), who took photos of the type specimens collected by Mozley. I am greatly indebted to ALAN KABAT (Associate in Malacology, MCZ, Harvard University) for sending me a plethora of American sources on Mozley's travel (mainly scans of the USA newspaper articles), which are almost unavailable from Russian libraries. Due to ALAN, I could know about the 'Siberian snails and Life on Mars' story. I could not use all the materials he sent me and limited myself to those of sources that are most closely related to the topic of my article (to use them all would mean to write a quite another paper). ALAN's numerous suggestions, which he made during the reviewing of this manuscript, as well as his efforts to polish my English were very helpful for me. I thank two other (anonymous) reviewers of my manuscript for their comments and suggestions.

ANONYMOUS 1936b. British biologist: brief research work in Australia. Hobart Mercury (Tasmania), 15 September 1936, p 6. (not seen; communicated by ALAN KABAT).

DOBZHANSKY TH. 1980. The birth of the genetic theory of evolution in the Soviet Union in the 1920s. In: MAYR E., Provine W. B. (eds). The evolutionary synthesis: perspectives on the unification of biology. Harvard University Press, Cambridge, pp. 229-242. https://doi. org/10.4159/harvard.9780674865389.c31

DRAVERT P. 1935. Mollyuski ozer kurorta "Borovoye” i nekotorykh drugikh okrestnykh vodoemov. Sbornik rabot po balneofizioterapii, kurortovedeniyu i kraevedniyu. Petropavlovsk 1: 70-72.

DYBOWSKI B. 1912. Bemerkungen und Zusatze zu der Arbeit von Dr. W. Dybowski "Mollusken aus der Uferregion des Baicalsees”. Ezhegodnik Zoologicheskogo Muzeya Imperatorskoy Akademii Nauk 17: 165-218.

DYBOWSKI W. 1912. Mollusken aus der Ufferregion des Baicalsees. Ezhegodnik Zoologicheskogo Muzeya Imperatorskoy Akademii Nauk 17: 123-143.

JOHANSEN B. 1934. The freshwater molluscs of Western Siberia. Proceedings of the Malacological Society of London 21: 28-36.

KAEMPFFERT W. 1936. The week in science: life at minus 40 degrees; climate of Siberia and that of Mars. New York Times, 12 January 1936, page 8. (not seen; communicated by ALAN KABAT)

KozHOV M. M. 1936. Mollyuski ozera Baikala: systematika, raspredelenie, ekologiya, nekotorye dannye po genezisu i istorii. Trudy Baikal'skoi Limnologicheskoi Stantsii (= Travaux de la Station Limnologique du Lac Baikal) 8: 1-350, 13 pls.

KREMENTSOV N. 1997. Stalinist science. Princeton University Press, Princeton, New Jersey. 
LindHOLM W. 1909. Die Mollusken des Baikalsees (Gastropoda et Pelecypoda) systematisch und zoogeographisch bearbeitet. Wissenschaftliche Ergebnisse einer zoologische Expedition nach dem Baikal-See unter Leitung des. Prof. Alexis Korotneff i. d. J. 1900-1902 4: 1-104.

Medvedev ZH. A. 1969. The rise and fall of T. D. Lysenko. Columbia University Press, New York. https://doi. org/10.7312/medv92664

MidDENDORFF A. VON 1851. Mollusken. In: MidDENDORFF A. VON. Reise in der äussersten Norden und Osten Sibiriens während der jahre 1843 und 1844. SaintPetersburg: Kaiserlichen Akademie der Wissenschaften. 2(1): 163-465.

MOZLEY W. A. 1934a. The freshwater and terrestrial Mollusca of Northern Asia, with notes on the Mollusca of Fennoscandia. Ph. D. Thesis, University of Edinburgh. https://era.ed.ac.uk/handle/1842/11862

MOZLEY A. 1934b. New fresh-water mollusks from northern Asia. Smithsonian Miscellaneous Collection 92: $1-7$.

MOZley A. 1934c. The discovery of Acanthinula harpa Say, in Central Siberia. Nature 133: 986. https://doi. org/10.1038/133986a0

MOZLEY A. 1935. The freshwater and terrestrial Mollusca of Northern Asia. Transactions of the Royal Society of Edinburgh 58: 605-695. https://doi.org/10.1017/ S0080456800004142

MOZLEY A. 1937a. The ponds, lakes and streams of the Kirghiz Steppe. Scottish Geographical Magazine 53: 1-10. https://doi.org/10.1080/00369223708735049

MOZLEY A. 1937b. Frozen ground in the Sub-Arctic region and its biological significance. Scottish Geographical Magazine 53: 266-270. https://doi. org/10.1080/00369223708735067

MOZLEY A. 1937c. A biological study of the Sub-Arctic Mollusca. Proceedings of the American Philosophical Society 78: 147-189.

MOZley A. 1938. The Sub-Arctic region as a molluscan habitat. Nature 142: 1116-1117. https://doi. org/10.1038/1421116b0

MOZLEY A. 1944. The control of Bilharzia in Southern Rhodesia. Rhodesian Printing \& Publishing Co., Salisbury.

MOZley A. 1951. The snail hosts of Bilharzia in Africa. H. K. Lewis \& Co., London.

MOZley A. 1954. An introduction to molluscan ecology: distributional and population studies of fresh-water Mollusca. H. K. Lewis \& Co., London.

MOZLEY A. 1957. Liver fluke snails in Britain. H. K. Lewis \& Co., London.

OsOKINA E. A. 2008. Za fasadom "stalinskogo izobiliya": Raspredelenie i rynok v snabzhenii naseleniya $\mathrm{v}$ gody industrializatsyi, 1927-1941 Second edition. Rosspen, Moscow.

POLlOCK E. 2009. From Partiinost' to Nauchnost' and not quite back again: Revisiting the lessons of the
Lysenko affair. Slavic Review 68: 95-114. https://doi. org/10.1017/S0037677900000103

RAPPAPORT R., SOMERS W. 2003. Mozley, Walter Alan. In: SOMERS W. (ed.). Encyclopedia of Union College History. Schenectady, New York, pp. 498-500.

ROKITYANSKY Y. G., VAVILOV Y. N., GONCHAROV V. A. 1999. Sud palacha: Nikolai Vavilov v zastenkakh NKVD: biograficheskiy ocherk, dokumenty. Academia, Moscow.

SCHRENCK L. VON 1867. Mollusken der Amur-Landes und des Nordjapanischen Meeres. In: SCHRENCK L. VON. Reisen und forschungen im Amur-Lande in der Jahren 1854-56, 2, pp. 259-974.

TAKHTEEV V. V., RUSINEK O. T. 2019. Vydayushchiysia issledovatel' Baikala. K 130-letiyu so dnia rozhdeniya G.Yu. Vereshchagina. Vestnik Rossiyskoy Akademii Nauk 89: 1062-1071.

TAYLOR D. W. 2003. Introduction to Physidae (Gastropoda: Hygrophila): Biogeography, classification, morphology. Revista de Biología Tropical 51. Supplement 1.

TikHov G. A. 1949. Astrobotanika. The Academy of Sciences of the Kazakh SSR Press, Alma-Ata.

VINARSKI M. V. 2010. Ocherk istorii izucheniya presnovodnoy malakofauny Sibiri (konets XVIII - seredina XX v.). Ruthenica 20: 45-67.

VINARSKI M. V. 2012. The lymnaeid genus Catascopia Meier-Brook et Bargues, 2002 (Mollusca: Gastropoda: Lymnaeidae), its synonymy and species composition. Invertebrate Zoology (Moscow) 9: 91-104. https://doi. org/10.15298/invertzool.09.2.02

VINARSKI M. V. 2014. Lymnaea likharevi Lazareva, 1967 is a junior synonym of Lymnaea saridalensis Mozley, 1934 (Gastropoda: Pulmonata: Lymnaeidae). Ruthenica 24: 35-44.

VINARSKI M. V. 2019. "Russkiy grazhdanin shvedskogo proiskhozhdeniya": Materialy $\mathrm{k}$ biografii W.A. Lindgolma. Trudy Zoologicheskogo Instituta RAN 323: 155-186. https://doi.org/10.31610/trudyzin/2019.323.3.155

VINARSKI M. V., KANTOR YU. I. 2016. Analytical catalogue of fresh and brackish water molluscs of Russia and adjacent countries. KMK Scientific Press, Moscow.

VINARSKI M. V., SCHNIEBS K., GLÖER P., SON M., HundsDoerfer A. 2012. The steppe relics: taxonomic study on two lymnaeid species endemic to the former USSR (Gastropoda: Pulmonata: Lymnaeidae). Archiv für Molluskenkunde 141: 67-85. https://doi. org/10.1127/arch.moll/1869-0963/141/067-085

Westerlund C. A. 1877. Sibiriens Land- och Sötvatten Mollusker. Konglige Svenska Vetenskaps-akademiens Handlingar 14: 1-112.

ZHADIN V. 1933. Presnovodnye mollyuski SSSR. OGIZLensnabtekhidat, Leningrad.

Received: April 12th, 2020

Revised: August 30th, 2020

Accepted: September 4th, 2020

Published on-line: October 9th, 2020 